"Mircea cel Batran" Naval Academy Scientific Bulletin, Volume XIX - 2016 - Issue 1

Published by "Mircea cel Batran" Naval Academy Press, Constanta, Romania // The journal is indexed in:

PROQUEST / DOAJ / DRJI / JOURNAL INDEX / I2OR / SCIENCE LIBRARY INDEX / Google Scholar / Crossref /

Academic Keys / ROAD Open Access / OAJI / Academic Resources / Scientific Indexing Services / SCIPIO

\title{
ALTERNATIVE FUELS FOR THE MARINE MARKET
}

Beazit ALI ${ }^{1}$

Levent $A \mathrm{AL}^{2}$

Adrian POPA ${ }^{3}$

Anastase PRUIU 4

${ }^{1}$ Marine Engineering and Naval Weapons Department, "Mircea cel Batran" Naval Academy, Constanta,

Professor PhD Eng., Romania

${ }^{2} \mathrm{PhD}$ attendee Eng., Bureau Veritas Romania Controle International, Constanta,Romania

${ }^{3}$ Senior Lecturer PhD Eng., Marine Engineering and Naval Weapons Department, "Mircea cel Batran" Naval Academy, Constanta, Romania

${ }^{4}$ Professor PhD Eng., Marine Engineering and Naval Weapons Department, "Mircea cel Batran" Naval Academy, Constanta, Romania

Abstract: The shipping industry is facing challenges to reduce exhaust gas emissions and greenhouse gases in particular, carbon dioxide from ships engaged in international trading. The main regulatory body, International Maritime Organization (IMO) and national environmental agencies of many countries have issued regulations that drastically reduce emissions coming from marine sources. Of particular note are regulations in Emissions Control Areas (ECAs) such as the North American ECA, which came into being in 2012, and the SOx Emission Control Areas (SECAs), which have been in effect in the Baltic Sea and North Sea and English Channel since 2006 and 2007, respectively. These new requirements will force ship owners and managers to look into other possibilities like using alternative fuels.

Keywords: gas emission, distilled fuel, biodiesel.

The biodiesel is manufactured from vegetable oils, vegetable fats and algae, and it is a renewable and clean fuel which is reducing exhaust gas emissions and greenhouse emissions from maritime applications. It is miscible with petroleum derivatives and can be mixed with heavy fuel oil or diesel oil in any proportion in order to burn in maritime diesel engines without major modifications on the fuel system. Other advantages of biodiesel includes biodegradability, high lubrication qualities for engine, very low greenhouse emissions and efficient combustion. Therefore it is an adequate alternative for emission reduction in diesel engines. Vegetable oils such as colza, soy, palm, algae, animal fat, which are in fact composed by triglycerides are used frequently for manufacturing biodiesel. The usage of this fuel is still limited in maritime industry compared with land industry applications. Its higher costs compared with conventional fuels is the major obstacle for its development and applicability.

A mixing rate of biodiesel $20 \%$ and conventional fuel $80 \%$ can reduce the costs on long term of the fuels for ship managers. Even if the fuel properties can be improved by mixing with biodiesel, there is no official study which predicts the characteristics of this blending.

\begin{tabular}{|l|l|l|l|l|}
\hline $\begin{array}{l}\text { Fuel } \\
\text { parameter }\end{array}$ & $\begin{array}{l}\text { Measuring } \\
\text { unit }\end{array}$ & $\begin{array}{l}\text { Residual } \\
\text { fuel }\end{array}$ & $\begin{array}{l}\text { Distilled } \\
\text { fuel }\end{array}$ & $\begin{array}{l}\text { Bio } \\
\text { diesel }\end{array}$ \\
\hline Cetane & - & 20 & 40 & 51 \\
\hline
\end{tabular}

DOI: 10.21279/1454-864X-16-I1-021

133

\begin{tabular}{|l|l|l|l|l|}
\hline number & & & & \\
\hline Sulphure & $\mathrm{ppm}$ & 45000 & 15000 & 10 \\
\hline $\begin{array}{l}\text { Density at } \\
15 \mathrm{C}\end{array}$ & $\mathrm{Kg} / \mathrm{m}^{3}$ & 920 & 890 & 860 \\
\hline $\begin{array}{l}\text { Flash } \\
\text { point }\end{array}$ & ${ }^{\circ} \mathrm{C}$ & 60 & 60 & 120 \\
\hline Carbon & $\%$ & 2,5 & 0,3 & 0,05 \\
\hline $\begin{array}{l}\text { Cinematic } \\
\text { viscosity }\end{array}$ & $\mathrm{mm}^{2} / \mathrm{s}$ & 10 & $2-6$ & $3,5-5$ \\
\hline $\begin{array}{l}\text { Water } \\
\text { content }\end{array}$ & $\mathrm{ppm}$ & 3000 & & 500 \\
\hline
\end{tabular}

Tabel 1. Fuels specifications:residual fuel, distilled fuel, biodiesel

Flash point is a significant indicator for storage, transport and combustion of the fuel. Conventional marine fuel, which has a flash point under $60^{\circ} \mathrm{C}$, cannot be stored under main deck according to SOLAS regulations. Flash point of biodiesel is bigger than petroleum derivates fuels, for example soy oil has the flashpoint approximately $138^{\circ} \mathrm{C}$.

Sulfur content of biodiesel is extremely low, blending it with any marine fossil fuel can reduce significantly deposits formation and reduce Sox emissions after combustion. The sulfur content of the blending is calculated based on the weight proportions of the components. For example, if $23 \%$ volume of biodiesel is added to the residual fuel, the sulfur content of $4,5 \%$ can be reduced to $3,5 \%$ which will be in accordance with requirements from 2012 regarding sulfur emissions of Annex VI MARPOL. 


\begin{abstract}
"Mircea cel Batran" Naval Academy Scientific Bulletin, Volume XIX - 2016 - Issue 1
Published by "Mircea cel Batran" Naval Academy Press, Constanta, Romania /I The journal is indexed in: PROQUEST / DOAJ / DRJI / JOURNAL INDEX / I2OR / SCIENCE LIBRARY INDEX / Google Scholar / Crossref /

Academic Keys / ROAD Open Access / OAJI / Academic Resources / Scientific Indexing Services / SCIPIO
\end{abstract}

Kinematic viscosity has the highest value for residual fuel, as shown in table 1 , compared with the other types of fuels, and it requires a larger amount of energy to be heated, reducing its viscosity before usage. The kinematic viscosity of the blending of biodiesel with marine fuel can significantly reduce the kinematic viscosity such that less energy is required to utilize the fuel.

Carbon residues is an indicator of combustion quality and is obtained based on the following formula: Carbon Residues(\%) = Carbon weight collected after burning of initial quantity of fuel. A lower value of carbon content implies a higher level of combustion quality. Therefore, the mix between conventional fuel and biodiesel causes an important reduction of carbon residues.As shown in table 1, after burning the residual fuel results 2,5\% carbon compared with $0,05 \%$ remaining after burning biodiesel. This lower value of carbon residues is attributed to chemical composition of biodiesel which contains less ash, very few contaminants and a very small fraction of aromatic compounds. Also the high level of oxygen from biodiesel composition, compared with fossil fuels, leads to a clean and more complete combustion, so less carbon resulted.

Exxon Mobil HDME 50 produced currently at Antwerp refineries, is a residual fuel with very low content of sulfur. This product was already testes on medium speed and low speed engines, but only at manufacturers sites and not on sea-trials. This fuels has a high pour point and it is paraffinic, requiring storage temperature between $30-40^{\circ} \mathrm{C}$. Even if HDME 50 has very low content of $\mathrm{Al}+\mathrm{Si}$, is still necessary to treat it in purifiers/separators and filters at less than 60 microns, with fuel inlet temperature of $60-70^{\circ} \mathrm{C}$ for a proper injection. If it is mixed with other fuels, there is a risk to loose its properties, especially in case of a big difference between the viscosity and density of the subjected fuels.

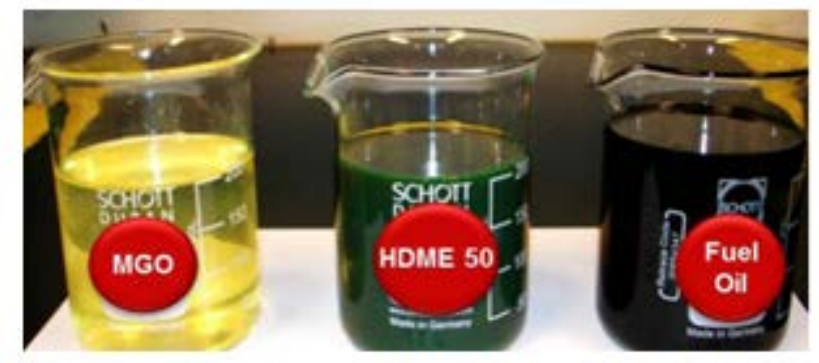

Source:"Everything you need to know about marine fuels", Chevron Technical Bulletin

Chemical comparison of the heavy fuel oil with HDME 5 cannot be done easily due to very different compositions of these types of fuels. For example cetane index is not applicable for HDME 5 , the product being clear, opaque and green color, originated from distillation processes. Also this new product has better combustion characteristics due to paraffinic property, ensuring less wear rate on the internal parts of the engine. Several tests were performed on two types of engines, 300 running hours on a 2 stroke propulsion engine MAN W7L7OMCE and 2000 running hour on a 4 stroke diesel generator MAN $6 \mathrm{~L} 28 / 32 \mathrm{H}$, in cooperation with several class societies.

\title{
CONCLUSION
}

Biofuels have not made inroads into the marine fuels market and given their limited availability and higher cost, we will probably not see large-scale use by ship operators as a neat fuel in the nearest future. Because they can be blended with conventional fuels, biofuels may find their way into the marine fuel market as they become more widely available, similar with HDME50, which will be interesting to see its development in the maritime industry.

\section{BIBLIOGRAPHY}

[1] Bureau of Energy Efficiency, Energy Efficiency in Thermal Utilities, 2004

[2]Caterpillar, Diesel Fuels and Diesel Fuel Systems, 2011

[3] DNVGL, Alternative Fuels for Shipping, 2013

[4] Chevron, Everything You Need to Know About Marine Fuels, 2012

[5]CIMAC, Guidelines ForShipowners and Operators on Managing Distillate Fuels, 2012 